Article

\title{
Migration in Spain: The Role of Cultural Diversity Revisited
}

\author{
Maite Alguacil ${ }^{1,2, *}$ and Luisa Alamá-Sabater ${ }^{1,3}$ \\ ${ }^{1}$ Department of Economics, Jaume I University, Spain; E-Mails: alguacil@uji.es (M.A.), alama@uji.es (L.A.-S.) \\ 2 Institute of International Economics, Jaume I University, Spain \\ ${ }^{3}$ Institute of Local Development, Jaume I University, Spain \\ * Corresponding author
}

Submitted: 30 April 2021 | Accepted: 2 July 2021 | Published: 28 October 2021

\begin{abstract}
In this article, we analyze to what extent cultural diversity brought about by immigrants affects economic activity of the Spanish provinces. To do that, we use panel data techniques that treat cultural diversity as an endogenous variable and account for spatial linkages. The dual nature of immigrants in Spain, that is, working and retired migration, is also considered in our regressions. The outcomes reveal that greater cultural diversity stimulates the economic activity of the Spanish provinces, these gains being reinforced in the case of labor-active migrant and for richer provinces. Our results are robust to diverse specifications, estimation methods, and samples.
\end{abstract}

\section{Keywords}

cultural diversity; economic development; migration; Spain

\section{Issue}

This article is part of the issue "Migration and Refugee Flows: New Insights" edited by Inmaculada Martínez-Zarzoso (University of Göttingen, Germany / Jaume I University, Spain).

(C) 2021 by the authors; licensee Cogitatio (Lisbon, Portugal). This article is licensed under a Creative Commons Attribution 4.0 International License (CC BY).

\section{Introduction}

The increasing inequalities between regions, climate change, and the exacerbation of conflicts in some developing areas have accentuated the migration flows in the world economy, with the consequent social and economic tension in host countries. According to the OECD (2020), OECD countries received about 5.3 million new permanent migrants in 2018, representing an increase of $2 \%$ compared to 2017 . Preliminary data for temporary migration flows in OECD countries also reflect an expected increase in 2019 compared to 2018. Although in 2020 the Covid-19 crisis has led to a reduction in these movements, a rebound in migratory movements it is expected by 2021 (OECD, 2020).

The entry of foreign people is especially remarkable in the case of Spain. From the end of the 20th century to the early years of the 21st century, this country has gone from being a net source of migrants to a net recipient, becoming one of the main target countries for immigrants in Europe. The share of the foreign popula- tion in Spain increased from $2 \%$ in 2000 to more than 12\% in 2017 (Alamá-Sabater et al., 2017). In 2018, Spain still ranked second among the countries of Europe in terms of receiving the most foreigners, with $6.2 \%$ more immigrants entering the country than in 2017. As shown by Delgado Gómez-Flors and Alguacil (2018), migration flows have made the Spanish population more diverse, not only culturally, but also spatially. Hence, the concern of this article is to understand the consequences of this mass immigration and the ensuing rise in cultural diversity. The expression "cultural diversity" used throughout this article refers to heterogeneous groups of people in terms of their birthplace. According to Docquier et al. (2020), culture and country of birth are closely related as the latter determines the language, education system, and social rules people were exposed to in their youth. Similarly, for Taras et al. (2010), the behavior of individuals in a society is strongly associated with the pattern observed in their birthplace. As in previous literature, we focus here on birthplace diversity from the first-generation international immigrants (see, among 
others, Cooke \& Kemeny, 2017; Ottaviano \& Peri, 2012; Rapoport, 2018). Concretely, we consider that a region is culturally more diverse when immigrants come from a higher number of birthplaces; or, in other words, when the probability that two migrants, randomly selected, were born in different countries is greater. A full representation of cultural diversity would require also considering to what extent migrants adopt the dominant culture of the host region or maintain their culture even passing this to the subsequent generations (Nijkamp \& Poot, 2015). However, in our case, data limitations have prevented us from using a more fitted measure of cultural diversity.

The motivation for this study stems from the ongoing debate concerning the effects that international migration has on destination countries. The increasing fear about the economic consequences of large-scale immigration flows and the absence of a coherent migration policy have led to growing social and political tension, which cannot always find a clear answer from the academia. The impact of migration on the employment and wages of native workers continues to be one of the recurring issues in the European public debate and one of the reasons behind the expansion of xenophobic movements on the political scene. Furthermore, given the technological advances produced within the new Industry 4.0, the less qualified native workers find themselves in an unfavorable position vis-à-vis the more qualified workers, sometimes blaming migrants for precipitating lower labor standards by accepting the less attractive jobs.

Based on the idea that heterogeneous groups of people might perform differently from homogeneous ones, a new wave of studies on international migration incorporate the effects of greater diversity into the discussion (for a review, see Delgado Gómez-Flors \& Alguacil, 2018). Several measures of cultural diversity related to international migration have been used in the literature, referring to ethnic identity, social or religious groups, or geographical origin (Bove \& Elia, 2017; Longhi, 2013; Nijkamp \& Poot, 2015).

According to this literature, the increasing diversity of the populations prompted by immigration might yield economic costs and benefits through different channels. The costs derived from immigrant diversity are usually related to the increasing difficulties of communication and cooperation across different ethnic groups (Bandiera et al., 2005). For Nijkamp and Poot (2015), if the cultural variety is too great, then social granularity can lead to excessive communication transaction costs, which can eventually reduce productivity. Besides, greater cultural diversity is associated with the creation of new ideas and innovation activities and with improvements in problem solving (Parrotta et al., 2014a). Immigrants' international social networks may further facilitate the connection of firms with foreign partners and transnational transactions (Möhlmann \& Bakens, 2015). Hence, immigration diversity might play a prominent role in promoting competitiveness, and this should be considered.
In this work, we examine the economic impact resulting from opening borders to new residents, considering the heterogeneous nature of migrants and their cultural diversity. After a comprehensive overview of the existing academic papers, we quantify how birthplace diversity brought about by immigration affects the economic activity of Spanish provinces. This question is of great importance for Spain, with a mass-scale and continuous entry of immigrants in recent years and with an unemployment rate that reached 26\% in 2013 (Alamá-Sabater et al., 2017). Even though this rate fell to about $13 \%$ before the Covid-19 era (in 2019), this country still presents nowadays the second highest unemployment rate among European Union (EU-27) member countries, only behind Greece (Eurostat, 2021).

This article makes two main contributions with respect to the previous related literature. Firstly, it analyses for the first time the connections between immigrant diversity and the economic performance of the Spanish provinces (NUTS 3). Secondly, our empirical analysis considers both the potential endogeneity of migration diversity and the spatial pattern associated to the economic indicators of Spanish provinces. To deal with these issues, as a novelty in the migration literature, we employ two-stage least-square (2SLS) estimators for spatial autoregressive models with endogenous regressors and instrumental variables (IV).

\section{Background}

Questions such as whether immigration harms or improves the opportunities of native workers or how it affects the economic performance of host countries have been studied in depth in empirical work with unclear and sometimes contradictory results (for a review, see Ottaviano \& Peri, 2012). Previous research, however, leaves the potential positive spillovers from greater heterogeneity of the population prompted by foreign migration in the background.

An array of recent empirical studies has attempted to clarify this issue but with ambiguous results. Some papers, at the regional scale, identify a clear positive impact of cultural diversity, coming from the presence of foreign citizens, on the economic development of the host market. Most of them focus on the effects on wages and productivity, based on the idea of a complementarity in production from more diverse immigrants (Bellini et al., 2013; Rapoport, 2018). The seminal paper on this matter is Ottaviano and Peri (2006). By using panel data from different American Metropolitan Statistical Areas, these authors confirmed the positive impact of immigration diversity on the average wage of US-born workers overall, both in the short and in the long run. Other authors that have found that immigrant diversity improves the economic development of this country are Sparber (2010), Ager and Brückner (2013), Kemeny and Cooke (2018), Docquier et al. (2020), and Rodríguez-Pose and von Berlepsch (2018). The benefits of diversity on 
wage, employment, or income per capita are also apparent when other developed economies are considered. This is the case of UK, Germany, and Spain, as shown by Nathan (2016), Suedekum et al. (2014), and Delgado Gómez-Flors and Alguacil (2018), respectively. In a similar vein, Bakens and de Graaff (2020) evidenced a positive correlation between individual productivity and migration diversity in the Netherlands. Another study by Bellini et al. (2013) revealed a positive effect of migration diversity on wages in 12 European regions. For Bove and Elia (2017), the positive effect of cultural diversity prompted by immigration flows is even more consistent in developing economies than in developed ones.

Other studies (most of them, but not all, centered on less developed countries) reveal a negative or a nonsignificant relationship between cultural diversity and the economic performance of the host regions, thus showing the relationship between natives and foreigners to be more one of substitution than of a complementary nature. Most of this literature contemplates cultural diversity as a factor of social destabilization and poor economic behavior, in many cases identifying cultural diversity with ethnic fractionalization and social polarization (Alesina \& Ferrara, 2005). Authors like Easterly and Levine (1997) and Collier and Gunning (1999) put forward ethnolinguistic fractionalization as a main reason for Africa's poor performance. For Montalvo and ReynalQuerol (2005), who analyzed a sample set of developing countries, a rise in social polarization has a negative impact on growth because it reduces the rate of investment and increases public consumption and the incidence of civil wars. By the same token, Churchill and Smyth (2017) found that ethnic and linguistic fractionalization helped to increase poverty levels in a group of developing countries and Campos et al. (2011) showed evidence of a negative effect of ethnic fractionalization on economic growth in a sample of 26 former centrallyplanned economies. Considering a developed economy, Longhi (2013) demonstrated that the positive correlation between diversity in English Local Authority Districts and workers' wages found in cross-sections disappears when we run panel estimations. Similarly, for Bakens et al. (2013), cultural diversity has no significant effect on average wages in Dutch cities.

The evidence at a micro level of the economic impact of cultural diversity is also quite vague. On the one hand, Trax et al. (2015) and Brunow and Nijkamp (2018) found that diversification of foreign workers in terms of nationalities increases productivity in German firms. In a similar vein, Böheim et al. (2012) showed that workforce heterogeneity leads to higher productivity and wages in Austrian firms. Conversely, for Parrotta et al. (2014b), workforce diversity in terms of birthplace is negatively associated with firm productivity in the case of Denmark. Nathan (2016) also revealed that the positive link between ethnic diversity and firm performance is not significant for the majority of UK firms, and is mainly concentrated in larger, high-turnover, knowledge- intensive enterprises. According to Brunow and Blien (2014), although German firms with higher worker diversity due to international immigration are more productive, their employment levels are lower.

Some studies have also analyzed the effects of labor diversity with workers from different education levels, showing that gains in economic activity derived from greater cultural diversity rely on the level of education. For Brunow and Nijkamp (2018), for instance, diversity of low-skilled employment appears not to yield productivity gains or losses, while different culture-specific knowledge of a high-skilled workforce has a positive effect on firm performance. Similarly, Docquier et al. (2020) found that the economic impact of migration diversity is positive among college-educated immigrants but not significant for less educated immigrants. Therefore, the impact of increased diversity associated with new and growing immigrant groups is still an open question that, far from being limited to a specific region or country, concerns the entire European society and there is still room for new research with updated methods and data.

\section{Stylized Facts}

\subsection{The Immigration Phenomenon in Spain}

The particular geographical location of countries in southern Europe has turned them into the "entrance hall" to the continent. The case of Spain is especially notorious. Throughout the first years of the 21st century (coinciding with the Spanish economic "boom"), more than five million immigrants arrived in Spain. With over 900,000 entries, this country became Europe's main target for immigrants in 2007 (Alamá-Sabater et al., 2014; Delgado Gómez-Flors \& Alguacil, 2018). A clear consequence of this mass migration was a rising percentage of foreigners over the total population in Spain since the beginning of this century.

As can be observed in Figure 1, the proportion of foreigners over the total population in this country increased from $2.2 \%$ in 2000 to $12.2 \%$ in 2010 . This upward tendency of the share of immigrants underwent a small decrease after 2010 , due primarily to the reduction in the migrant inflows (and the rise in the number of migrants leaving) that followed the crash of the construction sector and the subsequent loss of jobs. However, after 2017, with the economic recovery of the country, this percentage went back up again to reach a rate above $10 \%$ of the total population in 2018. In 2019, even after the financial crisis and the consequent reduction in the entry of foreigners during this period, Spain was still the fourth European country in terms of the number of immigrants, with a total foreign population of over five million and a percentage of immigrants in the total population exceeding $10.7 \%$ (Spanish National Institute of Statistics [INE], 2020).

The nature of its productive structure, with a high demand for non-qualified labor in a wide range 


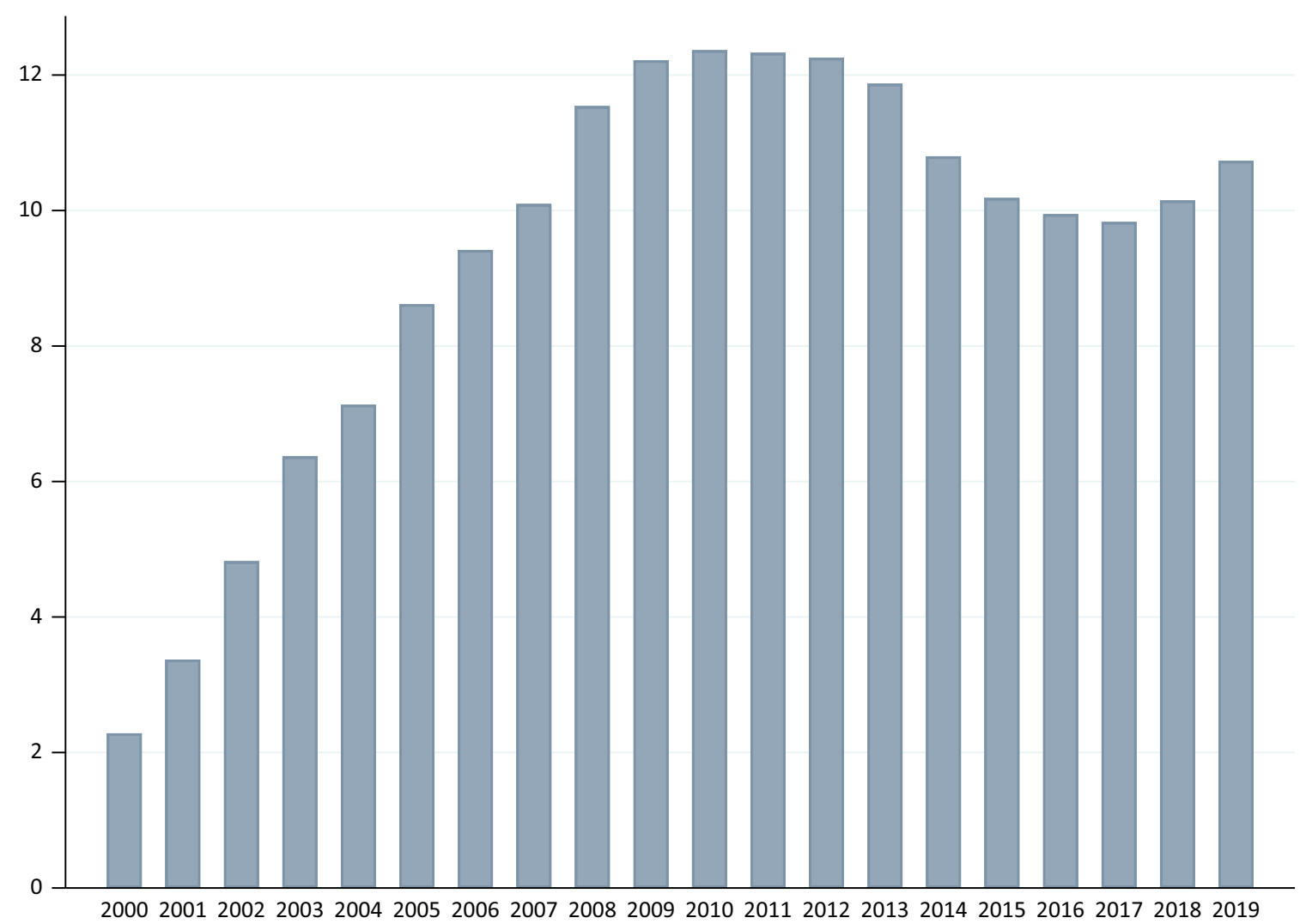

Figure 1. Share of foreign population in Spain, 1998-2019. Source: Authors' own elaboration based on Spanish National Institute of Statistics [INE] data.

of sectors, such as agriculture, or domestic service, together with the cultural linkages derived from the periods of colonialism, have converted this economy into an important recipient of foreigners, which are active at work (working or labor migration). These working migrants come mainly from developing economies, such as Morocco or Colombia. According to recent OECD data, the exodus of Moroccans to Spain and Italy has increased significantly in the last 15 years, making them currently the second and third destination countries, respectively, after France, in the EU for this African diaspora (OECD, 2020).

Promoting the inclusion of working immigrants has been a clear goal of the Spanish government and it recently approved a migration policy to order and regularize the entry of migrants into this country (Real Decreto-Ley $13 / 20$ ). These measures are aimed at facilitating the hiring of migrants, most of them coming from less developed regions, in the agricultural sector, thus solving the problem of the shortage of labor that is affecting agricultural production throughout Spain in the seasonal harvesting campaigns, especially aggravated by the Covid-19 crisis.

During the last years, the number of immigrants coming from developed countries has also increased, with the UK being the first country of origin of foreign residents in Spain from among the developed economies $(262,123$ British people were living in this country in
January 2020, according to the Spanish National Institute of Statistics [INE]). This is partly explained by the largescale regularization of British migrants who were already living in Spain after Brexit. Immigrants from other highly developed countries, like Italy and Germany, have also a great weight with respect to the total foreign population. The share of this migration, although smaller than that from developing economies, remains relevant with around $7 \%$ of the total foreign population during the period analyzed, 2002-2015, according to the INE.

\subsection{Birthplace Diversity in Spain}

To measure cultural diversity, we use the entropy index. For Parrotta et al. (2014a, 2014b) and Alesina et al. (2016), the entropy index provided a more accurate measure of diversity than the commonly used fractionalization index when the groups of nationalities are of different sizes. The entropy index is based on the Herfindahl concentration index combining two measures within one single indicator: the share of immigrants, irrespective of their birthplace, and the variety and relative size of immigrant groups with respect to natives. Its minimum value, zero, is obtained when the population is completely homogeneous in terms of origin. The entropy index reaches a maximum value of $\ln (R)$ when the population is completely heterogeneous, where $R$ is the maximum number of birthplaces in the population. 
In Figure 2, we represent the evolution of the entropy index $y$ in Spain (province average) over the sample period. As can be observed, until the outbreak of the crisis, the range of nationalities of immigrants grew steadily in this country, with only a partial slump during the period of the recession. This higher cultural diversity, however, is not homogenously distributed across provinces. The Mediterranean coastal provinces, the island provinces, and Madrid (where the capital city is located) present higher cultural diversity than the average (see Figure 3). The relevance of tourism and the evolution of the construction sector, together with speculative factors, have contributed to the clustering of different nationalities and to increasing the heterogeneity of the foreign population in the Mediterranean region and the capital city. In these provinces, it is common to find both types of immigrants: working immigrants and longstay or permanent tourists who locate outside the labor market (migrants over 55 years-old coming from highincome countries), thus giving rise to a wider range of nationalities and a higher cultural heterogeneity.

The degree of population heterogeneity in terms of nationalities also seems to be related to the economic performance of the different provinces. Figure 4 shows a clear positive relationship between the economic activity of the different provinces (measured by their level of GDP per capita) and birthplace diversity (represented by the entropy index), thereby confirming our initial idea about the economic gains from higher cultural hetero- geneity. However, this first approach does not control for provincial determinants that simultaneously affect both variables; neither does it consider the presence of temporal and spatial correlations. All these factors are considered in the econometric analysis shown in the following section.

\section{Empirical Analysis}

\subsection{Data and Estimation Model}

The study of the benefits derived from immigrant diversity is no easy task given the lack of detailed data. In our case, we built a database using information from both the INE and the Valencian Institute of Economic Research, which has allowed us to carry out the study at a NUTS 3 level for the period 2002-2015. Overall, our panel contains 14 yearly observations for 50 provinces. The estimation of panel-data models from these data allows us to account for both time effects and unobserved regional heterogeneity.

Following previous literature, the economic development of provinces is proxied here by the log of the GDP per capita. Other empirical papers that use this variable are Sparber (2010), Alesina et al. (2016), Cooke and Kemeny (2017), Docquier et al. (2020), and RodríguezPose and von Berlepsch (2018). Our main regressor, the heterogeneity of population across provinces, has been measured through the entropy index (as defined in the

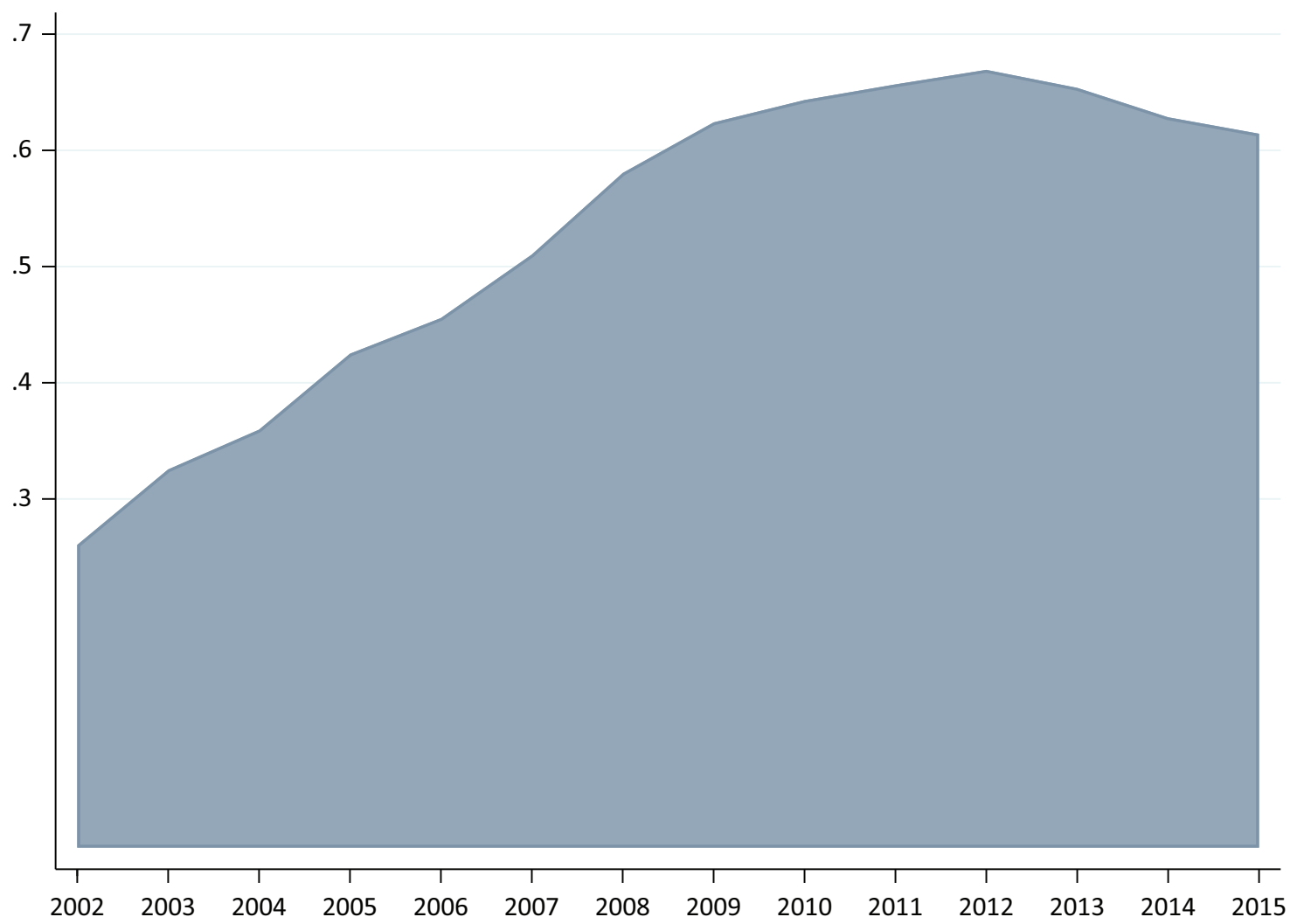

Figure 2. The average entropy index by provinces (birthplace diversity within the group of foreigners), 2002-2015. Source: Authors' own elaboration based on INE data. 
Entropy index (2002)

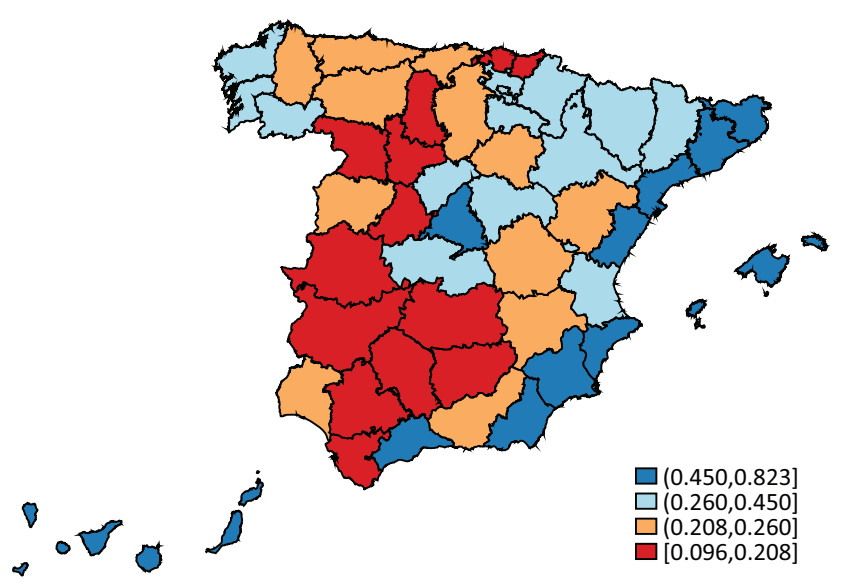

Entropy index (2015)

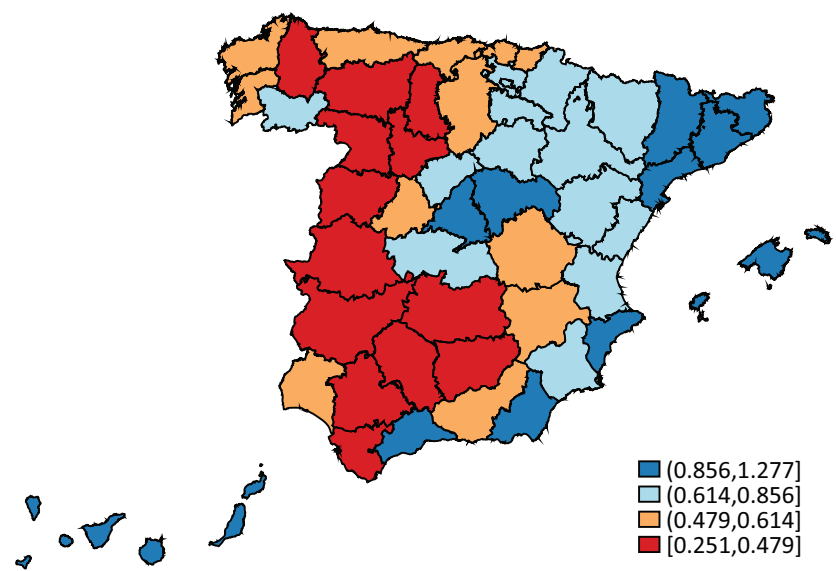

Figure 3. Diversity indexes by provinces. Source: Authors' own elaboration based on INE data.

previous section). Consistent with the related literature, we also controlled for other factors that influence the economic development of the different regions, such as the stock of physical capital (inv) or the level of skilled labor or human capital $(h k)$. This latter has been measured through the share of population that has reached a middle-high educational level. The level of education is also employed as a proxy of human capital in Bove and Elia (2017), Alesina et al. (2016), and Rodríguez-Pose and von Berlepsch (2018). Moreover, in line with Suedekum et al. (2014), we have included the share of workers that are employed in the industrial sector (ind). According to these authors, more industrialized regions are expected to have a more dynamic economic behavior and to be more export-oriented, which in turn may influence their cultural diversity. Additionally, we add the interprovincial net migration rate with respect to natives (netmigr) in order to capture other unobservable regional shocks (Suedekum et al., 2014). To disentangle the effects of birthplace diversity pertaining to the immigrant population from those of the size of immigration, we include the share of foreigners with respect to total population (migr_total). According to Docquier et al. (2020), this latter factor is an additional channel through which immigration may affect the economic performance of the provinces.

As a novelty in the literature, we further include two variables that represent immigrants in different

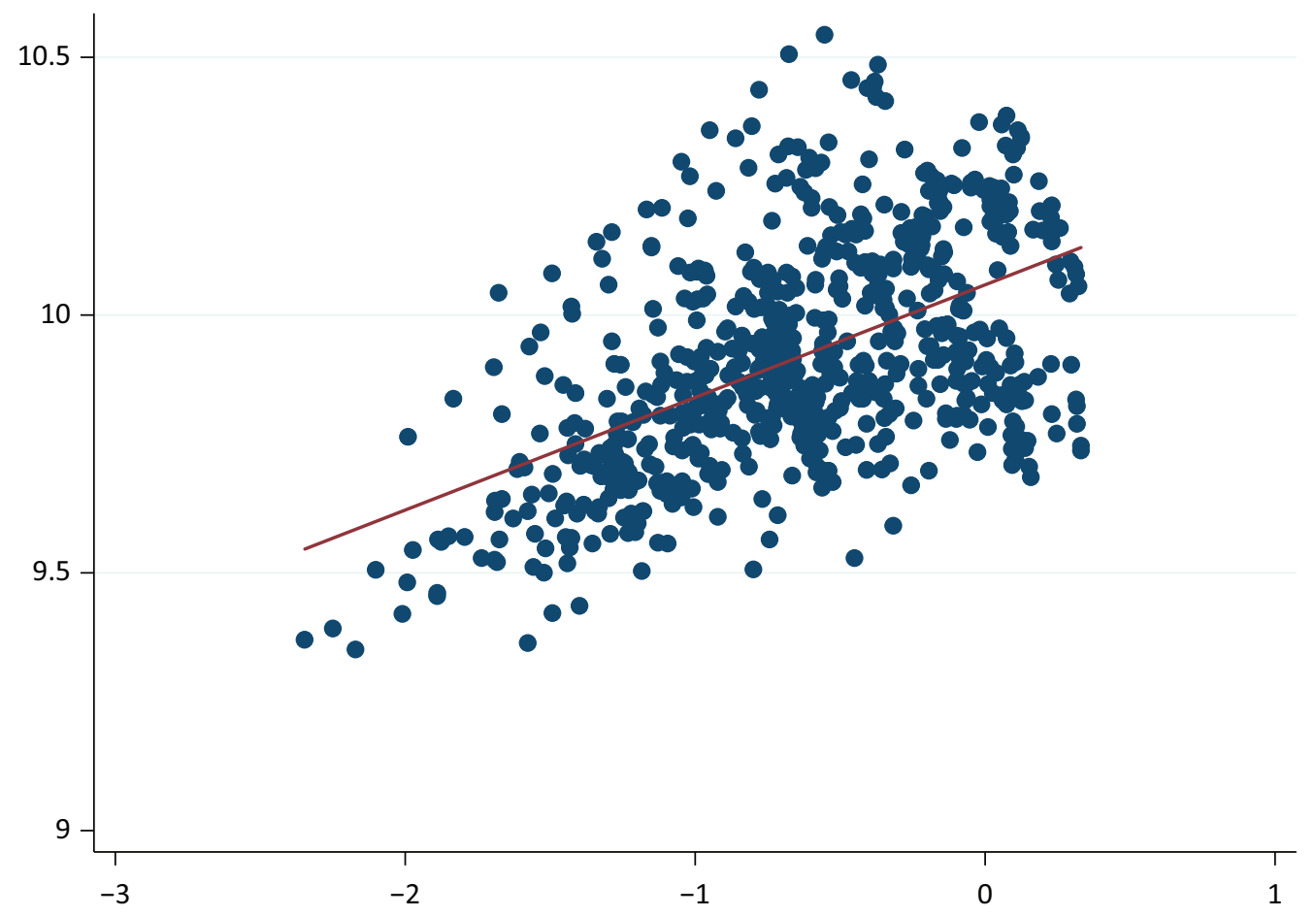

Figure 4. Correlation between birthplace diversity and economic activity, 2002-2015; entropy index vs. log(GDPpc). Source: Authors' own elaboration based on INE data. 
proportions according to their nature: working migrants (working_migr) and retired migrants (retired_migr). By so doing, we try to disentangle the impact that retired immigrants have on the economic prosperity of the specific areas of Spain, where they locate (mostly in coastal and island provinces) in comparison to the labor immigrants, who come mostly from countries with a lower level of economic development (and are more homogeneously distributed across regions).

\subsection{Main Results}

Table 1 presents the results for the GDP per capita regression using the fixed effects estimation methodology. As can be seen at the bottom of this table, the Hausman test suggests that in all cases the fixed effects model is preferred to the random effects model. In column (1), we can see the estimates of the basic model with investment, human capital, and industrialization index. We consider next, in column (2), also the rate of interprovincial net migration and share of total immi- grants as control variables. In column (3), we add the proportion of the two types of immigrants over the total population, that is, retired and working immigrants. Finally, columns (4) to (7) present the results with the interaction terms. Some collinearity problems have prevented us from adding both interaction terms simultaneously.

The most outstanding result of these regressions refers to the positive and highly significant coefficients of the index of birthplace diversity in all of them. This outcome is consistent with our key hypothesis concerning the economic benefits of a greater cultural heterogeneity of the population. Specifically, the estimated covariates imply that, on average, a $10 \%$ increase in the $E /$ leads to a rise in GDP per capita of between $0.57 \%$ and nearly $1 \%$, keeping other factors constant.

Additional conclusions stem from the estimates of the control variables. In line with previous studies on the determinants of growth, our outcomes confirm that regions with a higher rate of investment and human capital are also expected to have a better economic behavior (Bove \& Elia, 2017). As in Suedekum et al. (2014), the

Table 1. Estimation results of $\log (y)$ using fixed effects estimation, 2002-2015.

\begin{tabular}{|c|c|c|c|c|c|c|c|}
\hline Variables & (1) & $(2)$ & (3) & (4) & (5) & (6) & (7) \\
\hline EI & $\begin{array}{c}0.062 * * * \\
{[0.001]}\end{array}$ & $\begin{array}{c}0.099 * * * \\
{[0.000]}\end{array}$ & $\begin{array}{c}0.077^{* * *} \\
{[0.000]}\end{array}$ & $\begin{array}{c}0.068^{* * *} \\
{[0.000]}\end{array}$ & $\begin{array}{c}0.063^{* * *} \\
{[0.000]}\end{array}$ & $\begin{array}{l}0.061 * * * \\
{[0.002]}\end{array}$ & $\begin{array}{l}0.057^{* * *} \\
{[0.003]}\end{array}$ \\
\hline inv & $\begin{array}{l}0.060 * * * \\
{[0.000]}\end{array}$ & $\begin{array}{l}0.036^{* * *} \\
{[0.000]}\end{array}$ & $\begin{array}{l}0.034^{* * *} \\
{[0.000]}\end{array}$ & $\begin{array}{c}0.031 * * * \\
{[0.001]}\end{array}$ & $\begin{array}{l}0.026 * * * \\
{[0.006]}\end{array}$ & $\begin{array}{l}0.031 * * * \\
{[0.001]}\end{array}$ & $\begin{array}{l}0.026 * * * \\
{[0.006]}\end{array}$ \\
\hline$h k$ & $\begin{array}{c}0.419 * * * \\
{[0.000]}\end{array}$ & $\begin{array}{c}0.448^{* * *} \\
{[0.000]}\end{array}$ & $\begin{array}{c}0.430 * * * \\
{[0.000]}\end{array}$ & $\begin{array}{c}0.495^{* * *} \\
{[0.000]}\end{array}$ & $\begin{array}{c}0.466 * * * \\
{[0.000]}\end{array}$ & $\begin{array}{l}0.466 * * * \\
{[0.000]}\end{array}$ & $\begin{array}{l}0.451 * * * \\
{[0.000]}\end{array}$ \\
\hline ind & $\begin{array}{l}0.044^{* * *} \\
{[0.000]}\end{array}$ & $\begin{array}{c}0.042 * * * \\
{[0.000]}\end{array}$ & $\begin{array}{l}0.038^{* * *} \\
{[0.000]}\end{array}$ & $\begin{array}{l}0.044^{* * *} \\
{[0.000]}\end{array}$ & $\begin{array}{l}0.040 * * * \\
{[0.000]}\end{array}$ & $\begin{array}{l}0.040 * * * \\
{[0.000]}\end{array}$ & $\begin{array}{l}0.036 * * * \\
{[0.000]}\end{array}$ \\
\hline netmigr & & $\begin{array}{l}0.002 * * * \\
{[0.000]}\end{array}$ & $\begin{array}{l}0.002 * * * \\
{[0.000]}\end{array}$ & $\begin{array}{l}0.002 * * * \\
{[0.000]}\end{array}$ & $\begin{array}{l}0.002 * * * \\
{[0.000]}\end{array}$ & $\begin{array}{l}0.002 * * * \\
{[0.000]}\end{array}$ & $\begin{array}{l}0.003^{* * *} \\
{[0.000]}\end{array}$ \\
\hline migr_total & & $\begin{array}{l}-0.014 * * * \\
{[0.000]}\end{array}$ & $\begin{array}{l}-0.013 * * * \\
{[0.000]}\end{array}$ & $\begin{array}{l}-0.020 * * * \\
{[0.000]}\end{array}$ & $\begin{array}{l}-0.012 * * * \\
{[0.000]}\end{array}$ & $\begin{array}{l}-0.018 * * * \\
{[0.000]}\end{array}$ & $\begin{array}{l}-0.012^{* * *} \\
{[0.000]}\end{array}$ \\
\hline working_migr & & & $\begin{array}{c}0.450 * * \\
{[0.012]}\end{array}$ & & & $\begin{array}{c}0.382 * * \\
{[0.035]}\end{array}$ & $\begin{array}{c}0.435^{* *} \\
{[0.014]}\end{array}$ \\
\hline retired_migr & & & $\begin{array}{c}0.291 \\
{[0.115]}\end{array}$ & & & $\begin{array}{c}0.256 \\
{[0.166]}\end{array}$ & $\begin{array}{c}0.339 * \\
{[0.063]}\end{array}$ \\
\hline El*working_migr & & & & $\begin{array}{l}0.188^{* * *} \\
{[0.001]}\end{array}$ & & $\begin{array}{c}0.131^{* *} \\
{[0.029]}\end{array}$ & \\
\hline El*retired_migr & & & & & $\begin{array}{l}-0.297 * * * \\
{[0.000]}\end{array}$ & & $\begin{array}{l}-0.266^{* * *} \\
{[0.000]}\end{array}$ \\
\hline Constant & $\begin{array}{c}9.141 * * * \\
{[0.000]}\end{array}$ & $\begin{array}{c}9.517 * * * \\
{[0.000]}\end{array}$ & $\begin{array}{c}9.123 * * * \\
{[0.000]}\end{array}$ & $\begin{array}{c}9.502 * * * \\
{[0.000]}\end{array}$ & $\begin{array}{c}9.589 * * * \\
{[0.000]}\end{array}$ & $\begin{array}{l}9.171 * * * \\
{[0.000]}\end{array}$ & $\begin{array}{l}9.192 * * * \\
{[0.000]}\end{array}$ \\
\hline Observations & 700 & 700 & 700 & 700 & 700 & 700 & 700 \\
\hline R-squared & 0.874 & 0.914 & 0.916 & 0.915 & 0.917 & 0.917 & 0.919 \\
\hline \# provinces & 50 & 50 & 50 & 50 & 50 & 50 & 50 \\
\hline Time effects & Yes & Yes & Yes & Yes & Yes & Yes & Yes \\
\hline Fixed effects & Yes & Yes & Yes & Yes & Yes & Yes & Yes \\
\hline Hausman test & $83.76 * * *$ & $92.38 * * *$ & $116.23 * * *$ & $105.23 * * *$ & $115.08 * * *$ & $103.83 * * *$ & $126.55^{* * *}$ \\
\hline
\end{tabular}

Notes: ${ }^{* *} p<0.01 ;{ }^{* *} p<0.05 ;{ }^{*} p<0.1 ; p$-value in brackets. 
industrialization index and the net immigration rate are positively associated with the economic development of provinces. Finally, our outcomes show a negative influence on macroeconomic performance arising from the total share of the foreign population once we take into account the positive influence of greater birthplace diversity. This result is similar to that Suedekum et al. (2014), who analyzed the impact of cultural diversity on wages and employment in Germany. As these authors point out, this finding should not be interpreted by itself, without additional evidence, as a displacement effect of native workers by foreigners. The negative impact of the share of total migration includes both demand and supply factors. The entry of immigrants with lower income gains on average might favor a reduction in the aggregate income from the demand side, while it might still stimulate the economic behavior from the supply side. Moreover, in our case, the small coefficient on total migration does not compromise the beneficial effects of an increased heterogeneity of the population. In addition, the positive impact of cultural diversity remains even when this variable is not considered, showing that our main result is not conditional on the negative effect of total migration.

Additionally, our findings reveal that the presence of working migrants is positively related to the economic prosperity of provinces, whereas the influence of retired immigrants is less relevant. This result would be consistent with the idea of an elderly foreign population from highly developed countries that is outside the productive process and has a reduced economic effect. The interaction terms also reflect a differentiated effect of both types of migration: While greater diversity among working migrants improves the economic activity, in contrast, in the case of older migrants from advanced countries, this greater diversity can curb economic development.

\subsubsection{Endogeneity and Spatial Dependence}

To deal with potential endogeneity issues and to identify the source of the correlation between cultural diversity and economic prosperity that is due exclusively to the influence of population heterogeneity, we estimate the model using two-stage regression techniques with instrumental variables. Following previous literature, the difficulties related to the selection of an appropriate IV are solved by building the instrument for the variable of interest (cultural diversity) according to the procedure referred to as the "shift-share methodology," where the population heterogeneity at a regional level is compared to the population composition at the national level.

In concrete, to estimate our instrument, we used the current total immigration rates and the changes of immigrants from each region in the previous period to estimate the "attributed" share of people born in that region residing in a specific province. Next, the predicted diversity index is obtained using the attributed share of foreignborn individuals that has been previously computed. The intuition behind this instrument relies on the fact that the initial share of immigrants by country of origin can be considered a good predictor of subsequent migration inflows, as migrants tend to be attracted to regions where other immigrants from the same country locate (Gagliardi, 2015). By definition, this index does not depend on any regional economic shock in the current period.

The results obtained in the IV estimation model are shown in Table 2. In line with previous results, the coefficients on the cultural diversity indexes are positive and highly significant in all cases. However, now the effect of birthplace diversity is slightly smaller than in the fixed effects regression, reflecting the upward bias of the initial estimation. The validity of the instrument has been tested using both the Anderson canon underindentification and the Stock-Yogo weak identification statistics. The results obtained confirm that the IV is relevant and does not suffer from weak identification problems (both tests are rejected at the $5 \%$ level in all cases). The firststage regression and the validity tests for the IV are available in the Supplementary File.

Another potential problem that we should address when dealing with local indicators refers to the spatial dependence between regions, as the economic performance of a region also depends on how well the neighbor economies behave (Artelaris \& Petrakos, 2016). As far as we know, the only study that controls for this spatial connection in the regional impact of cultural diversity on economic performance is Suedekum et al. (2014). Specifically, they estimated the effect that diversity has on a native's wages in Germany assuming a spatial correlation in the error terms. In this article, instead, we perform spatial autoregressive models that include endogenous regressors to control for both the correlation of the dependent variable across provinces and the dependence on the error term.

To confirm the presence of spatial autocorrelation, as a first step, we perform the Moran test for spatial correlation among the residuals (see Table 3 ). In all cases, the Moran test leads us to reject the possibility that the errors are identically and independently distributed, thereby confirming the hypothesis that the incomes of provinces are also affected by the economic conditions of neighboring regions and not only by the specific home factors. Accordingly, we estimated the model through a two-stage least-square estimator with endogenous regressors based on feasible instruments (Hoshino, 2017; Liu \& Lee, 2013). This method allows us to introduce other explanatory variables, such as endogenous variables, into the model, in addition to the spatial lag dependent variable (Elhorst, 2010).

In order to select the model that best fits the spatial structure, we ran the Lagrange multiplier (LM) test for the spatially lagged dependent variable (LM spatial lag) and the spatial autocorrelated error term (LM spatial error). Spatial diagnosis indicates that the value of the LM spatial lag is higher than the LM spatial error in Models 2, 3, 5, and 7, while the LM spatial error is higher for Models 1, 4, and 6. Accordingly, we have added 
Table 2. Estimation results of $\log (y)$ using two-stage least-square IV estimation, 2002-2015.

\begin{tabular}{|c|c|c|c|c|c|c|c|}
\hline Variables & (1) & (2) & (3) & (4) & (5) & (6) & (7) \\
\hline El & $\begin{array}{l}0.053^{* * *} \\
{[0.004]}\end{array}$ & $\begin{array}{l}0.079 * * * \\
{[0.000]}\end{array}$ & $\begin{array}{c}0.054^{* * *} \\
{[0.006]}\end{array}$ & $\begin{array}{c}0.036^{*} \\
{[0.068]}\end{array}$ & $\begin{array}{c}0.034^{*} \\
{[0.062]}\end{array}$ & $\begin{array}{c}0.045^{* *} \\
{[0.024]}\end{array}$ & $\begin{array}{c}0.038^{* *} \\
{[0.044]}\end{array}$ \\
\hline inv & $\begin{array}{l}0.063^{* * *} \\
{[0.000]}\end{array}$ & $\begin{array}{l}0.038^{* * *} \\
{[0.000]}\end{array}$ & $\begin{array}{l}0.036^{* * *} \\
{[0.000]}\end{array}$ & $\begin{array}{l}0.033^{* * *} \\
{[0.000]}\end{array}$ & $\begin{array}{l}0.028^{* * *} \\
{[0.003]}\end{array}$ & $\begin{array}{l}0.032^{* * *} \\
{[0.001]}\end{array}$ & $\begin{array}{l}0.027^{* * *} \\
{[0.004]}\end{array}$ \\
\hline$h k$ & $\begin{array}{l}0.518^{* * *} \\
{[0.000]}\end{array}$ & $\begin{array}{l}0.465^{* * *} \\
{[0.000]}\end{array}$ & $\begin{array}{l}0.443^{* * *} \\
{[0.000]}\end{array}$ & $\begin{array}{l}0.528^{* * *} \\
{[0.000]}\end{array}$ & $\begin{array}{l}0.490^{* * *} \\
{[0.000]}\end{array}$ & $\begin{array}{l}0.478^{* * *} \\
{[0.000]}\end{array}$ & $\begin{array}{l}0.462^{* * *} \\
{[0.000]}\end{array}$ \\
\hline ind & $\begin{array}{l}0.045^{* * *} \\
{[0.000]}\end{array}$ & $\begin{array}{l}0.045^{* * *} \\
{[0.000]}\end{array}$ & $\begin{array}{l}0.042^{* * *} \\
{[0.000]}\end{array}$ & $\begin{array}{l}0.049 * * * \\
{[0.000]}\end{array}$ & $\begin{array}{l}0.044^{* * *} \\
{[0.000]}\end{array}$ & $\begin{array}{l}0.042^{* * *} \\
{[0.000]}\end{array}$ & $\begin{array}{l}0.038^{* * *} \\
{[0.000]}\end{array}$ \\
\hline netmigr & & $\begin{array}{l}0.002^{* * *} \\
{[0.000]}\end{array}$ & $\begin{array}{l}0.002^{* * *} \\
{[0.000]}\end{array}$ & $\begin{array}{l}0.002^{* * *} \\
{[0.000]}\end{array}$ & $\begin{array}{l}0.002^{* * *} \\
{[0.000]}\end{array}$ & $\begin{array}{l}0.002^{* * *} \\
{[0.000]}\end{array}$ & $\begin{array}{l}0.002^{* * *} \\
{[0.000]}\end{array}$ \\
\hline migr_total & & $\begin{array}{l}-0.014^{* * *} \\
{[0.000]}\end{array}$ & $\begin{array}{l}-0.013^{* * *} \\
{[0.000]}\end{array}$ & $\begin{array}{l}-0.022^{* * *} \\
{[0.000]}\end{array}$ & $\begin{array}{l}-0.012^{* * *} \\
{[0.000]}\end{array}$ & $\begin{array}{l}-0.018^{* * *} \\
{[0.000]}\end{array}$ & $\begin{array}{l}-0.011^{* * *} \\
{[0.000]}\end{array}$ \\
\hline working_migr & & & $\begin{array}{c}0.419^{* *} \\
{[0.017]}\end{array}$ & & $\begin{array}{c}0.326^{*} \\
{[0.068]}\end{array}$ & $\begin{array}{c}0.356^{* *} \\
{[0.046]}\end{array}$ & $\begin{array}{c}0.411^{* *} \\
{[0.018]}\end{array}$ \\
\hline retired_migr & & & $\begin{array}{c}0.229 \\
{[0.210]}\end{array}$ & & & $\begin{array}{c}0.216 \\
{[0.235]}\end{array}$ & $\begin{array}{c}0.295^{*} \\
{[0.099]}\end{array}$ \\
\hline working_migr*EI & & & & $\begin{array}{l}0.238^{* * *} \\
{[0.000]}\end{array}$ & & $\begin{array}{c}0.169 * * * \\
{[0.005]}\end{array}$ & \\
\hline retired_migr*El & & & & & $\begin{array}{l}-0.337^{* * *} \\
{[0.000]}\end{array}$ & & $\begin{array}{l}-0.281^{* * *} \\
{[0.000]}\end{array}$ \\
\hline Observations & 700 & 700 & 700 & 700 & 700 & 700 & 700 \\
\hline R-squared & 0.8668 & 0.914 & 0.916 & 0.915 & 0.917 & 0.917 & 0.918 \\
\hline \# provinces & 50 & 50 & 50 & 50 & 50 & 50 & 50 \\
\hline Time effecs & Yes & Yes & Yes & Yes & Yes & Yes & Yes \\
\hline Fixed effects & Yes & Yes & Yes & Yes & Yes & Yes & Yes \\
\hline
\end{tabular}

Notes: $* * * p<0.01 ; * * p<0.05 ; * p<0.1 ; p$-value in brackets.

spatial lag regressors in both the dependent variable and the error term. Although we have estimated the model using different spatial distance structures, for the sake of brevity, in Table 3 we display the results obtained using the inverse square distance between units.

As can be seen, the diversity index is positive and highly significant in all regressions, thus ratifying our previous result. However, as expected, the effect of birthplace diversity is slightly smaller than in the fixed effects and IV regressions. In particular, our model now predicts that when the entropy index increases by $10 \%$ in a specific province, its income per capita will rise by between $3.8 \%$ and $7.3 \%$, other factors remaining constant.

The spatial lag (rho) parameter is positive and significant in all the models, indicating the presence of spatial connections in GDP per capita across provinces. Table 3 also reveals that $\lambda$, the spatial correlation parameter in the error term is significant in Models 1, 3, 4, 6, and 7, thus confirming the presence of non-observable effects in neighboring regions.

The coefficients of the rest of the control variables remain significant and with the expected signs. In line with our previous results, a higher proportion of immigrants from countries with a medium income positively influences the economic activity of the regions. With a lower impact, older immigration that originally came from countries with high incomes also has a positive effect on income. Again, the interaction terms reveal a divergent effect of both types of migration.

\section{Robustness}

\subsection{Quantile Regression}

To analyze how the impact of cultural diversity changes at different quantiles of the income per capita (and not only on its mean value), next we estimate a quantile regression ( $Q R$ ). The outcomes of the $Q R$ confirm the significant relationship between diversity and the economic performance of provinces (see Table 4). The coefficients on $E I$ have a positive sign in all quantiles and the mean. With the exception of the first quantile in the general model, all of them are also significant. This confirms that provinces with a more heterogeneous population have a better economic behavior. Nonetheless, the effect of migration diversity on income increases progressively from the lowest to the highest quantiles, revealing a non-linear relationship between these variables. The impact of cultural diversity on the economic activity is greater in provinces with higher income. 
Table 3. Estimation results of $\log (y)$ using two-stage least-square estimators for spatial autoregressive models (GS2SLS estimates), 2002-2015.

\begin{tabular}{|c|c|c|c|c|c|c|c|}
\hline Variables & (1) & $(2)$ & (3) & (4) & (5) & (6) & (7) \\
\hline$\rho Y$ & $\begin{array}{l}0.792^{* * *} \\
{[0.000]}\end{array}$ & $\begin{array}{l}0.292^{* * *} \\
{[0.000]}\end{array}$ & $\begin{array}{l}0.619 * * * \\
{[0.000]}\end{array}$ & $\begin{array}{l}0.489 * * * \\
{[0.000]}\end{array}$ & $\begin{array}{l}0.373^{* * *} \\
{[0.000]}\end{array}$ & $\begin{array}{l}0.613^{* * *} \\
{[0.000]}\end{array}$ & $\begin{array}{l}0.602 * * * \\
{[0.000]}\end{array}$ \\
\hline$\lambda \varepsilon$ & $\begin{array}{l}-0.490 * * * \\
{[0.000]}\end{array}$ & $\begin{array}{c}0.096 \\
{[0.292]}\end{array}$ & $\begin{array}{l}-0.337^{* * *} \\
{[0.000]}\end{array}$ & $\begin{array}{l}-0.217^{* *} \\
{[0.026]}\end{array}$ & $\begin{array}{l}-0.108 \\
{[0.256]}\end{array}$ & $\begin{array}{l}-0.357^{* * *} \\
{[0.000]}\end{array}$ & $\begin{array}{l}-0.368^{* * *} \\
{[0.000]}\end{array}$ \\
\hline El & $\begin{array}{c}0.0290^{*} \\
{[0.070]}\end{array}$ & $\begin{array}{l}0.073^{* * *} \\
{[0.000]}\end{array}$ & $\begin{array}{l}0.063^{* * *} \\
{[0.000]}\end{array}$ & $\begin{array}{c}0.038 * * \\
{[0.028]}\end{array}$ & $\begin{array}{l}0.045^{* * *} \\
{[0.008]}\end{array}$ & $\begin{array}{c}0.047^{* *} \\
{[0.012]}\end{array}$ & $\begin{array}{l}0.057^{* * *} \\
{[0.001]}\end{array}$ \\
\hline $\operatorname{inv}$ & $\begin{array}{l}0.047^{* * *} \\
{[0.000]}\end{array}$ & $\begin{array}{l}0.034^{* * *} \\
{[0.000]}\end{array}$ & $\begin{array}{l}0.029 * * * \\
{[0.000]}\end{array}$ & $\begin{array}{l}0.029 * * * \\
{[0.001]}\end{array}$ & $\begin{array}{l}0.028^{* * *} \\
{[0.001]}\end{array}$ & $\begin{array}{l}0.027^{* * *} \\
{[0.001]}\end{array}$ & $\begin{array}{l}0.025^{* * *} \\
{[0.003]}\end{array}$ \\
\hline$h k$ & $\begin{array}{l}0.338^{* * *} \\
{[0.001]}\end{array}$ & $\begin{array}{l}0.407^{* * *} \\
{[0.000]}\end{array}$ & $\begin{array}{l}0.352^{* * *} \\
{[0.000]}\end{array}$ & $\begin{array}{l}0.426 * * * \\
{[0.000]}\end{array}$ & $\begin{array}{l}0.418^{* * *} \\
{[0.000]}\end{array}$ & $\begin{array}{l}0.387^{* * * *} \\
{[0.000]}\end{array}$ & $\begin{array}{l}0.361^{* * *} \\
{[0.000]}\end{array}$ \\
\hline ind & $\begin{array}{l}0.0502^{* * *} \\
{[0.000]}\end{array}$ & $\begin{array}{l}0.049 * * * \\
{[0.000]}\end{array}$ & $\begin{array}{l}0.038^{* * *} \\
{[0.000]}\end{array}$ & $\begin{array}{l}0.046 * * * \\
{[0.000]}\end{array}$ & $\begin{array}{l}0.045^{* * *} \\
{[0.000]}\end{array}$ & $\begin{array}{l}0.039 * * * \\
{[0.000]}\end{array}$ & $\begin{array}{l}0.036 * * * \\
{[0.000]}\end{array}$ \\
\hline netmigr & & $\begin{array}{l}0.002^{* * *} \\
{[0.000]}\end{array}$ & $\begin{array}{l}0.002^{* * *} \\
{[0.000]}\end{array}$ & $\begin{array}{l}0.002^{* * *} \\
{[0.000]}\end{array}$ & $\begin{array}{l}0.002^{* * *} \\
{[0.000]}\end{array}$ & $\begin{array}{l}0.002^{* * *} \\
{[0.000]}\end{array}$ & $\begin{array}{l}0.002^{* * *} \\
{[0.000]}\end{array}$ \\
\hline migrtotal & & $\begin{array}{l}-0.012 * * * \\
{[0.000]}\end{array}$ & $\begin{array}{l}-0.009 * * * \\
{[0.000]}\end{array}$ & $\begin{array}{l}-0.015 * * * \\
{[0.000]}\end{array}$ & $\begin{array}{l}-0.010 * * * \\
{[0.000]}\end{array}$ & $\begin{array}{l}-0.013 * * * \\
{[0.000]}\end{array}$ & $\begin{array}{l}-0.009 * * * \\
{[0.000]}\end{array}$ \\
\hline workingmigr & & & $\begin{array}{c}0.374^{* *} \\
{[0.018]}\end{array}$ & & & $\begin{array}{c}0.300 * \\
{[0.063]}\end{array}$ & $\begin{array}{c}0.364^{* *} \\
{[0.021]}\end{array}$ \\
\hline retiredmigr & & & $\begin{array}{c}0.353^{* *} \\
{[0.032]}\end{array}$ & & & $\begin{array}{c}0.306^{*} \\
{[0.064]}\end{array}$ & $\begin{array}{c}0.373^{* *} \\
{[0.023]}\end{array}$ \\
\hline working_mig*EI & & & & $\begin{array}{l}0.153^{* * *} \\
{[0.004]}\end{array}$ & & $\begin{array}{c}0.113^{* *} \\
{[0.032]}\end{array}$ & \\
\hline retired_migr*EI & & & & & $\begin{array}{l}-0.191 * * * \\
{[0.001]}\end{array}$ & & $\begin{array}{c}-0.117^{* *} \\
{[0.033]}\end{array}$ \\
\hline Observations & 700 & 700 & 700 & 700 & 700 & 700 & 700 \\
\hline R-squared & 0.978 & 0.985 & 0.984 & 0.985 & 0.986 & 0.985 & 0.985 \\
\hline \# provinces & 50 & 50 & 50 & 50 & 50 & 50 & 50 \\
\hline Time effects & Yes & Yes & Yes & Yes & Yes & Yes & Yes \\
\hline Fixed effects & Yes & Yes & Yes & Yes & Yes & Yes & Yes \\
\hline Wald test of: spatial term & $120.56 * * *$ & $62.15^{* * *}$ & $146.08 * * *$ & $91.49 * * *$ & $47.79 * * *$ & $140.85^{* * *}$ & $116.67 * * *$ \\
\hline \multicolumn{4}{|c|}{ Diagnostic tests for spatial dependence } & \multicolumn{4}{|c|}{ Inverse-square distance } \\
\hline Moran's I (error) & $3.47 * * *$ & $23.76 * * *$ & $22.24 * * *$ & $22.05^{* * *}$ & $22.87 * * *$ & $21.181^{* * *}$ & $22.18 * * *$ \\
\hline LM (lag) & 0.348 & $547.41 * * *$ & $476.09 * * *$ & $469.09 * * *$ & $505.26 * * *$ & $430.14 * * *$ & $472.23 * * *$ \\
\hline Robust LM (lag) & $5.719 * *$ & $94.30 * * *$ & $91.04 * * *$ & $81.50 * * *$ & $92.254 * * *$ & $64.57 * * *$ & $84.75^{* * *}$ \\
\hline LM (error) & $11.34 * * *$ & $529.57 * * *$ & $456.02 * * *$ & $474.29 * * *$ & $491.92 * * *$ & $461.86^{* * *}$ & $464.09 * * *$ \\
\hline Robust LM (error) & $16.71 * * *$ & $76.45^{* * *}$ & $70.97 * * *$ & $86.69 * * *$ & $78.91 * * *$ & $96.29 * * *$ & $76.61 * * *$ \\
\hline
\end{tabular}

Notes: ${ }^{* * *} p<0.01 ; * * p<0.05 ;{ }^{*} p<0.1 ; p$-value in brackets.

The estimates of the different control variables have, in general, similar signs in all quantiles and the mean, indicating that the impact of these variables, although they may be different in magnitude and significance, is consistent in terms of direction. With respect to the two types of migration, we only have a positive and significant sign on working migration for the 0.2 and 0.8 quantiles, but not for the mean values of our dependent variables. This agrees with the existence of heterogeneities and non-linearity in the links between migration variety and economic development.

\subsection{Coastal Provinces vs. Inland Provinces}

In Tables 5 and 6, we present the estimates of GDP per capita, with coastal and inland provinces considered separately. Results in all the regressions confirm the positive impact of cultural diversity on income, although the coefficients on $\mathrm{El}$ are higher and more significant for coastal provinces than for inland provinces. The results with respect to inv, $h k$, ind, netmigr and migr_total are, in general, in line with our previous results from the whole sample. 
Table 4. Quantile regression of $\log (y), 2002-2015$. General model.

\begin{tabular}{|c|c|c|c|c|c|}
\hline Variables & $Q_{y}(0.2 \mid x)$ & $Q_{y}(0.4 \mid x)$ & $Q_{y}(0.6 \mid x)$ & $Q_{y}(0.8 \mid x)$ & Median $-Q_{y}(0.5 \mid x)$ \\
\hline$E I$ & $\begin{array}{c}0.031 \\
{[0.225]}\end{array}$ & $\begin{array}{c}0.052 * \\
{[0.069]}\end{array}$ & $\begin{array}{c}0.065^{* *} \\
{[0.012]}\end{array}$ & $\begin{array}{c}0.128^{* * *} \\
{[0.000]}\end{array}$ & $\begin{array}{c}0.052 * \\
{[0.078]}\end{array}$ \\
\hline inv & $\begin{array}{c}0.018 \\
{[0.183]}\end{array}$ & $\begin{array}{c}0.037^{* *} \\
{[0.011]}\end{array}$ & $\begin{array}{c}0.017 \\
{[0.188]}\end{array}$ & $\begin{array}{c}0.021 \\
{[0.107]}\end{array}$ & $\begin{array}{c}0.029 * \\
{[0.051]}\end{array}$ \\
\hline$h k$ & $\begin{array}{c}0.261^{* *} \\
{[0.046]}\end{array}$ & $\begin{array}{l}0.392^{* * *} \\
{[0.006]}\end{array}$ & $\begin{array}{l}0.430 * * * \\
{[0.001]}\end{array}$ & $\begin{array}{c}0.249 * \\
{[0.059]}\end{array}$ & $\begin{array}{l}0.493 * * * \\
{[0.001]}\end{array}$ \\
\hline ind & $\begin{array}{c}0.033^{* *} \\
{[0.012]}\end{array}$ & $\begin{array}{c}0.035^{* *} \\
{[0.017]}\end{array}$ & $\begin{array}{c}0.029 * * \\
{[0.027]}\end{array}$ & $\begin{array}{c}0.030 * * \\
{[0.023]}\end{array}$ & $\begin{array}{c}0.031^{* *} \\
{[0.036]}\end{array}$ \\
\hline netmigr & $\begin{array}{c}0.003 * * * \\
{[0.000]}\end{array}$ & $\begin{array}{l}0.003 * * * \\
{[0.000]}\end{array}$ & $\begin{array}{c}0.003 * * * \\
{[0.000]}\end{array}$ & $\begin{array}{l}0.002 * * * \\
{[0.001]}\end{array}$ & $\begin{array}{c}0.003 * * * \\
{[0.000]}\end{array}$ \\
\hline migr_total & $\begin{array}{l}-0.012 * * * \\
{[0.000]}\end{array}$ & $\begin{array}{l}-0.014 * * * \\
{[0.000]}\end{array}$ & $\begin{array}{l}-0.012 * * * \\
{[0.000]}\end{array}$ & $\begin{array}{l}-0.013 * * * \\
{[0.000]}\end{array}$ & $\begin{array}{l}-0.014 * * * \\
{[0.000]}\end{array}$ \\
\hline workingmigr & $\begin{array}{c}0.518^{* *} \\
{[0.038]}\end{array}$ & $\begin{array}{c}0.199 \\
{[0.466]}\end{array}$ & $\begin{array}{c}0.146 \\
{[0.561]}\end{array}$ & $\begin{array}{c}0.416^{*} \\
{[0.098]}\end{array}$ & $\begin{array}{c}0.072 \\
{[0.800]}\end{array}$ \\
\hline retiredmigr & $\begin{array}{c}0.414 \\
{[0.107]}\end{array}$ & $\begin{array}{c}0.131 \\
{[0.643]}\end{array}$ & $\begin{array}{l}-0.010 \\
{[0.970]}\end{array}$ & $\begin{array}{c}0.323 \\
{[0.212]}\end{array}$ & $\begin{array}{l}-0.017 \\
{[0.954]}\end{array}$ \\
\hline Constant & $\begin{array}{c}9.537^{* * *} \\
{[0.000]}\end{array}$ & $\begin{array}{l}9.695^{* * *} \\
{[0.000]}\end{array}$ & $\begin{array}{l}9.971 * * * \\
{[0.000]}\end{array}$ & $\begin{array}{l}9.806 * * * \\
{[0.000]}\end{array}$ & $\begin{array}{l}9.876 * * * \\
{[0.000]}\end{array}$ \\
\hline Observations & 700 & 700 & 700 & 700 & 700 \\
\hline
\end{tabular}

Notes: ${ }^{* * *} p<0.01 ;{ }^{* *} p<0.05 ;{ }^{*} p<0.1 ; p$-value in brackets.

The most remarkable difference with respect to the initial estimates refers mainly to the impact of the two types of migration. While for the inland provinces, the positive effect of population heterogeneity seems to come primarily through labor migration, for the coastal provinces, this effect is not so clear. Additionally, we find that in the coastal provinces, a higher heterogeneity of the permanent tourist stresses the positive impact of cultural diversity, while in the inland provinces this effect is negative.

\section{Conclusions}

The opening of borders within EU and the increasing migration from Africa and other neighboring areas have led to a high concern about the economic impact of international migration and the related growth of population heterogeneity. In this article, we analyze to what extent cultural diversity brought about by international migration contributes to an improvement or to a deterioration of the economic activity, focusing on the particular case of the Spanish provinces.

The massive waves of immigration to Spain since the end of the last century have turned this country into one of the European Union (EU-27) member states with the highest proportion of foreigners. Moreover, compared to other migration stories in the developed world, there is a striking peculiarity in the pattern of migration in Spain: the presence, together with a great amount of working migration, of a significant proportion of residential tourists or retired migrants.
To quantify the consequences of opening up the borders to new residents, we employ the entropy index based on birthplace as a measure of cultural diversity. The potential simultaneity between migration heterogeneity and economic activity has been controlled for by the shift-share methodology. Moreover, as a novelty in the related literature, we have considered the spatial pattern associated to the diverse economic indicators of Spanish provinces, introducing the spatial dependence of variables and the error term. We also present estimates for quantiles of the dependent variable and for different sample compositions (coastal and inland provinces) to verify the robustness of our empirical strategy.

The results obtained are in line with previous studies, confirming that greater cultural diversity boosts the per capita output of the Spanish provinces. However, according to our quantile regressions this is not a linear effect, as the impact of diversity is greater in richer provinces. In addition, our outcomes confirm the beneficial influence of domestic capital, skilled labor, and a higher rate of industrialization on economic prosperity. We also find a significant influence of the interprovincial net migration rate. Finally, the estimates reveal the importance of the working migration to encourage economic development in the Spanish provinces, this being especially reinforced in the case of the inland provinces.

Overall, we can conclude that despite the sui generis nature of recent immigration in Spain and the strong economic linkages among provinces, the cultural heterogeneity in regions is revealed here as something 
Table 5. Estimation results of $\log (y)$ using fixed effects estimation, 2002-2015. Inland provinces.

\begin{tabular}{|c|c|c|c|c|c|c|}
\hline Variables & (1) & (2) & (3) & (4) & (5) & (6) \\
\hline$E I$ & $\begin{array}{c}0.082^{* * *} \\
{[0.000]}\end{array}$ & $\begin{array}{c}0.060 * * \\
{[0.011]}\end{array}$ & $\begin{array}{c}0.055^{* *} \\
{[0.016]}\end{array}$ & $\begin{array}{c}0.015 \\
{[0.478]}\end{array}$ & $\begin{array}{c}0.050 * * \\
{[0.041]}\end{array}$ & $\begin{array}{c}0.021 \\
{[0.362]}\end{array}$ \\
\hline inv & $\begin{array}{c}0.024^{* *} \\
{[0.033]}\end{array}$ & $\begin{array}{c}0.021 * \\
{[0.052]}\end{array}$ & $\begin{array}{c}0.020 * \\
{[0.068]}\end{array}$ & $\begin{array}{c}0.007 \\
{[0.500]}\end{array}$ & $\begin{array}{c}0.019 * \\
{[0.079]}\end{array}$ & $\begin{array}{c}0.005 \\
{[0.648]}\end{array}$ \\
\hline$h k$ & $\begin{array}{c}0.406^{* * *} \\
{[0.000]}\end{array}$ & $\begin{array}{c}0.388^{* * *} \\
{[0.001]}\end{array}$ & $\begin{array}{c}0.427^{* * *} \\
{[0.000]}\end{array}$ & $\begin{array}{c}0.363^{* * *} \\
{[0.001]}\end{array}$ & $\begin{array}{c}0.404 * * * \\
{[0.000]}\end{array}$ & $\begin{array}{l}0.348^{* * *} \\
{[0.001]}\end{array}$ \\
\hline ind & $\begin{array}{l}0.046^{* * *} \\
{[0.000]}\end{array}$ & $\begin{array}{l}0.039 * * * \\
{[0.000]}\end{array}$ & $\begin{array}{l}0.046^{* * *} \\
{[0.000]}\end{array}$ & $\begin{array}{l}0.045^{* * *} \\
{[0.000]}\end{array}$ & $\begin{array}{l}0.040 * * * \\
{[0.000]}\end{array}$ & $\begin{array}{l}0.037^{* * *} \\
{[0.000]}\end{array}$ \\
\hline netmigr & $\begin{array}{l}0.001 * * * \\
{[0.005]}\end{array}$ & $\begin{array}{l}0.002 * * * \\
{[0.003]}\end{array}$ & $\begin{array}{l}0.001 * * * \\
{[0.007]}\end{array}$ & $\begin{array}{l}0.002^{* * *} \\
{[0.000]}\end{array}$ & $\begin{array}{l}0.001 * * * \\
{[0.003]}\end{array}$ & $\begin{array}{l}0.002^{* * *} \\
{[0.000]}\end{array}$ \\
\hline migr_total & $\begin{array}{l}-0.012^{* * *} \\
{[0.000]}\end{array}$ & $\begin{array}{l}-0.011 * * * \\
{[0.000]}\end{array}$ & $\begin{array}{l}-0.019 * * * \\
{[0.000]}\end{array}$ & $\begin{array}{l}-0.009 * * * \\
{[0.000]}\end{array}$ & $\begin{array}{l}-0.016 * * * \\
{[0.000]}\end{array}$ & $\begin{array}{l}-0.010 * * * \\
{[0.000]}\end{array}$ \\
\hline work_tour & & $\begin{array}{c}0.477^{* *} \\
{[0.017]}\end{array}$ & & & $\begin{array}{c}0.457^{* *} \\
{[0.022]}\end{array}$ & $\begin{array}{l}0.580 * * * \\
{[0.002]}\end{array}$ \\
\hline retired_migr & & $\begin{array}{c}0.310 \\
{[0.145]}\end{array}$ & & & $\begin{array}{c}0.330 \\
{[0.121]}\end{array}$ & $\begin{array}{l}0.561 * * * \\
{[0.006]}\end{array}$ \\
\hline El*working_migr & & & $\begin{array}{c}0.210^{* *} \\
{[0.012]}\end{array}$ & & $\begin{array}{c}0.134 \\
{[0.134]}\end{array}$ & \\
\hline$E I^{*}$ retired_migr & & & & $\begin{array}{l}-0.540 * * * \\
{[0.000]}\end{array}$ & & $\begin{array}{l}-0.546^{* * *} \\
{[0.000]}\end{array}$ \\
\hline Constant & $\begin{array}{l}9.598^{* * *} \\
{[0.000]}\end{array}$ & $\begin{array}{l}9.183^{* * *} \\
{[0.000]}\end{array}$ & $\begin{array}{l}9.584 * * * \\
{[0.000]}\end{array}$ & $\begin{array}{l}9.718^{* * *} \\
{[0.000]}\end{array}$ & $\begin{array}{c}9.187^{* * *} \\
{[0.000]}\end{array}$ & $\begin{array}{l}9.193^{* * *} \\
{[0.000]}\end{array}$ \\
\hline Observations & 434 & 434 & 434 & 434 & 434 & 434 \\
\hline R-squared & 0.917 & 0.920 & 0.919 & 0.928 & 0.920 & 0.930 \\
\hline \# provinces & 31 & 31 & 31 & 31 & 31 & 31 \\
\hline Time effects & Yes & Yes & Yes & Yes & Yes & Yes \\
\hline Fixed effects & Yes & Yes & Yes & Yes & Yes & Yes \\
\hline
\end{tabular}

Notes: ${ }^{* *} p<0.01 ; * *<0.05 ; * p<0.1 ; p$-value in brackets. 
Table 6. Estimation results of $\log (y)$ using fixed effects estimation, 2002-2015. Coastal provinces.

\begin{tabular}{|c|c|c|c|c|c|c|}
\hline Variables & (1) & (2) & (3) & (4) & (5) & (6) \\
\hline EI & $\begin{array}{c}0.119 * * * \\
{[0.000]}\end{array}$ & $\begin{array}{c}0.069 * * \\
{[0.029]}\end{array}$ & $\begin{array}{c}0.127^{* * *} \\
{[0.000]}\end{array}$ & $\begin{array}{l}0.136^{* * *} \\
{[0.000]}\end{array}$ & $\begin{array}{l}0.092 * * * \\
{[0.010]}\end{array}$ & $\begin{array}{c}0.076 * * \\
{[0.014]}\end{array}$ \\
\hline inv & $\begin{array}{l}0.074^{* * *} \\
{[0.000]}\end{array}$ & $\begin{array}{l}0.072^{* * *} \\
{[0.000]}\end{array}$ & $\begin{array}{l}0.075^{* * *} \\
{[0.000]}\end{array}$ & $\begin{array}{l}0.078^{* * *} \\
{[0.000]}\end{array}$ & $\begin{array}{l}0.077^{* * *} \\
{[0.000]}\end{array}$ & $\begin{array}{l}0.079 * * * \\
{[0.000]}\end{array}$ \\
\hline$h k$ & $\begin{array}{l}0.494^{* * *} \\
{[0.003]}\end{array}$ & $\begin{array}{l}0.448^{* * *} \\
{[0.007]}\end{array}$ & $\begin{array}{l}0.471^{* * *} \\
{[0.007]}\end{array}$ & $\begin{array}{c}0.414^{* *} \\
{[0.015]}\end{array}$ & $\begin{array}{c}0.361^{* *} \\
{[0.039]}\end{array}$ & $\begin{array}{c}0.281 * \\
{[0.094]}\end{array}$ \\
\hline ind & $\begin{array}{l}-0.044 \\
{[0.138]}\end{array}$ & $\begin{array}{l}-0.055^{*} \\
{[0.065]}\end{array}$ & $\begin{array}{l}-0.049 \\
{[0.121]}\end{array}$ & $\begin{array}{l}-0.049 * \\
{[0.097]}\end{array}$ & $\begin{array}{l}-0.071^{* *} \\
{[0.026]}\end{array}$ & $\begin{array}{l}-0.069 * * \\
{[0.020]}\end{array}$ \\
\hline netmigr & $\begin{array}{l}0.003^{* * *} \\
{[0.000]}\end{array}$ & $\begin{array}{c}0.003^{* * *} \\
{[0.000]}\end{array}$ & $\begin{array}{l}0.003^{* * *} \\
{[0.000]}\end{array}$ & $\begin{array}{l}0.003^{* * *} \\
{[0.000]}\end{array}$ & $\begin{array}{l}0.003^{* * *} \\
{[0.000]}\end{array}$ & $\begin{array}{l}0.003^{* * *} \\
{[0.000]}\end{array}$ \\
\hline migr_total & $\begin{array}{l}-0.017^{* * *} \\
{[0.000]}\end{array}$ & $\begin{array}{l}-0.015^{* * *} \\
{[0.000]}\end{array}$ & $\begin{array}{l}-0.016^{* * *} \\
{[0.000]}\end{array}$ & $\begin{array}{l}-0.019 * * * \\
{[0.000]}\end{array}$ & $\begin{array}{l}-0.011^{* * *} \\
{[0.001]}\end{array}$ & $\begin{array}{l}-0.018^{* * *} \\
{[0.000]}\end{array}$ \\
\hline working_migr & & $\begin{array}{l}-0.106 \\
{[0.811]}\end{array}$ & & & $\begin{array}{c}0.109 \\
{[0.817]}\end{array}$ & $\begin{array}{c}0.015 \\
{[0.972]}\end{array}$ \\
\hline retired_migra & & $\begin{array}{l}-0.347 \\
{[0.440]}\end{array}$ & & & $\begin{array}{l}-0.180 \\
{[0.698]}\end{array}$ & $\begin{array}{l}-0.354 \\
{[0.421]}\end{array}$ \\
\hline EI*working_migr & & & $\begin{array}{l}-0.040 \\
{[0.645]}\end{array}$ & & $\begin{array}{l}-0.135 \\
{[0.156]}\end{array}$ & \\
\hline EI*retired_migr & & & & $\begin{array}{c}0.196^{* *} \\
{[0.041]}\end{array}$ & & $\begin{array}{l}0.348^{* * *} \\
{[0.001]}\end{array}$ \\
\hline Constant & $\begin{array}{l}9.158^{* * *} \\
{[0.000]}\end{array}$ & $\begin{array}{l}9.329 * * * \\
{[0.000]}\end{array}$ & $\begin{array}{l}9.161^{* * *} \\
{[0.000]}\end{array}$ & $\begin{array}{l}9.130 * * * \\
{[0.000]}\end{array}$ & $\begin{array}{l}9.135^{* * *} \\
{[0.000]}\end{array}$ & $\begin{array}{l}9.192^{* * *} \\
{[0.000]}\end{array}$ \\
\hline Observations & 266 & 266 & 266 & 266 & 266 & 266 \\
\hline R-squared & 0.927 & 0.930 & 0.927 & 0.929 & 0.930 & 0.933 \\
\hline \# provinces & 19 & 19 & 19 & 19 & 19 & 19 \\
\hline Time effects & Yes & Yes & Yes & Yes & Yes & Yes \\
\hline Fixed effects & Yes & Yes & Yes & Yes & Yes & Yes \\
\hline
\end{tabular}

Notes: ${ }^{* *} p<0.01 ;{ }^{* *} p<0.05 ;{ }^{*} p<0.1 ; p$-value in brackets.

beneficial for the economic performance. Thus, some of the inferences from previous literature that contemplate migration as an obstacle for economic growth might not hold as they ignore the benefits that stem from a more heterogeneous population.

The issue of cultural diversity is considered one of the major challenges for European policy makers in current times. However, the question of how EU external migration policy should evaluate the potential gains of a higher cultural diversity will require further research on this issue, with data that are more detailed and a broader analysis, distinguishing across economic sectors and focusing on smaller territorial units.

\section{Acknowledgments}

Authors would like to thank the Universitat Jaume I (UJI-B2020-57) for their financial support. Luisa AlamáSabater also acknowledges the financial support of the Spanish Ministry of Economy and Finance (ECO201785746-P, GACVUJI/2021/09) and the Valencian Autonomous Government (GV-HIECPU/2020/1).

\section{Conflict of Interests}

The authors declare no conflict of interests.

\section{Supplementary Material}

Supplementary material for this article is available online in the format provided by the author (unedited).

\section{References}

Ager, P., \& Brückner, M. (2013). Cultural diversity and economic growth: Evidence from the US during the age of mass migration. European Economic Review, 64, 76-97.

Alamá-Sabater, L., Alguacil, M., \& Bernat-Martí, J. S. (2014). Location determinants of migrant inflows: The Spanish case. In J. S. Carrasco \& J. F. Dasí (Eds.), Identity and territorial character: Re-interpreting local-spatial development (pp. 81-97). University of Valencia.

Alamá-Sabater, L., Alguacil, M., \& Bernat-Martí, J. S. (2017). New patterns in the locational choice of immi- 
grants in Spain. European Planning Studies, 25(10), 1834-1855.

Alesina, A., \& Ferrara, E. L. (2005). Ethnic diversity and economic performance. Journal of Economic Literature, 43(3), 762-800.

Alesina, A., Harnoss, J., \& Rapoport, H. (2016). Birthplace diversity and economic prosperity. Journal of Economic Growth, 21(2), 101-138.

Artelaris, P., \& Petrakos, G. (2016). Intraregional spatial inequalities and regional income level in the European Union: Beyond the inverted-U hypothesis. International Regional Science Review, 39(3), 291-317.

Bakens, J., \& de Graaff, T. (2020). Valuation of ethnic diversity: Heterogeneous effects in an integrated labor and housing market. Journal of Economic Geography, 20(1), 197-223.

Bakens, J., Mulder, P., \& Nijkamp, P. (2013). Economic impacts of cultural diversity in the Netherlands: Productivity, utility, and sorting. Journal of Regional Science, 53(1), 8-36.

Bandiera, O., Barankay, I., \& Rasul, I. (2005). Cooperation in collective action. Economics of Transition, 13(3), 473-498.

Bellini, E., Ottaviano, G. I., Pinelli, D., \& Prarolo, G. (2013). Cultural diversity and economic performance: Evidence from European regions. In R. Crescenzi \& M. Percoco (Eds.), Geography, institutions and regional economic performance (pp. 121-141). Springer.

Böheim, R., Horvath, T., \& Mayr, K. (2012). Birthplace diversity of the workforce and productivity spill-overs in firms (Working Paper No. 438). WIFO Working Papers.

Bove, V., \& Elia, L. (2017). Migration, diversity, and economic growth. World Development, 89, 227-239.

Brunow, S., \& Blien, U. (2014). Effects of cultural diversity on individual establishments. International Journal of Manpower, 35(1/2), 166-186.

Brunow, S., \& Nijkamp, P. (2018). The impact of a culturally diverse workforce on firms' revenues and productivity: An empirical investigation on Germany. International Regional Science Review, 41(1), 62-85.

Campos, N. F., Saleh, A., \& Kuzeyev, V. (2011). Dynamic ethnic fractionalization and economic growth. The Journal of International Trade \& Economic Development, 20(2), 129-152.

Churchill, S. A., \& Smyth, R. (2017). Ethnic diversity and poverty. World Development, 95, 285-302.

Cooke, A., \& Kemeny, T. (2017). The economic geography of immigrant diversity: Disparate impacts and new directions. Geography Compass, 11(11), Article e12331.

Collier, P., \& Gunning, J. W. (1999). Explaining African economic performance. Journal of Economic Literature, 37(1), 64-111.

Delgado Gómez-Flors, M., \& Alguacil, M. (2018). The impact of immigrant diversity on wages. The Spanish experience. Sustainability, 10(9), Article 3312.

Docquier, F., Turati, R., Valette, J., \& Vasilakis, C. (2020).
Birthplace diversity and economic growth: Evidence from the US states in the Post-World War II period. Journal of Economic Geography, 20(2), 321-354.

Easterly, W., \& Levine, R. (1997). Africa's growth tragedy: Policies and ethnic divisions. The Quarterly Journal of Economics, 112(4), 1203-1250.

Elhorst, P. (2010). Applied spatial econometrics: Raising the bar. Spatial Economic Analysis, 5(1), 1742-1772.

Eurostat. (2021). Unemployment rate-annual data. [Data set]. https://ec.europa.eu/eurostat/ databrowser/view/tipsun20/default/table?lang=en

Gagliardi, L. (2015). Does skilled migration foster innovative performance? Evidence from British local areas. Papers in Regional Science, 94(4), 773-794.

Hoshino, T. (2017). Semiparametric spatial autoregressive models with endogenous regressors: With an application to crime data. Journal of Business \& Economic Statistics, 36(1), 160-172.

Kemeny, T., \& Cooke, A. (2018). Spillovers from immigrant diversity in cities. Journal of Economic Geography, 18(1), 213-245.

Liu, X., \& Lee, L. (2013). Two-stage least square estimation of spatial autoregressive models with endogenous regressors and many instruments. Journal of Econometric Reviews, 32(5), 734-753.

Longhi, S. (2013). Impact of cultural diversity on wages, evidence from panel data. Regional Science and Urban Economics, 43(5), 797-807.

Möhlmann, J., \& Bakens, J. (2015). Ethnic diversity and firm productivity in the Netherlands. In P. Nijkamp, J. Poot, \& J. Bakens (Eds.), The economics of cultural diversity. Edward Elgar Publishing.

Montalvo, J. G., \& Reynal-Querol, M. (2005). Ethnic diversity and economic development. Journal of Development Economics, 76(2), 293-323.

Nathan, M. (2016). Ethnic diversity and business performance: Which firms? Which cities? Environment and Planning A: Economy and Space, 48(12), 2462-2483.

Nijkamp, P., \& Poot, J. (2015). Cultural diversity: A matter of measurement. In P. Nijkamp, J. Poot, \& J. Bakens (Eds.), The economics of cultural diversity (pp. 17-51). Edward Elgar Publishing.

OECD. (2020). International migration outlook 2020. OECD Publishing. https://doi.org/10.1787/ec98f531en

Ottaviano, G. I., \& Peri, G. (2006). The economic value of cultural diversity: Evidence from US cities. Journal of Economic Geography, 6(1), 9-44.

Ottaviano, G. I., \& Peri, G. (2012). Rethinking the effect of immigration on wages. Journal of the European Economic Association, 10(1), 152-197.

Parrotta, P., Pozzoli, D., \& Pytlikova, M. (2014a). The nexus between labor diversity and firm's innovation. Journal of Population Economics, 27(2), 303-364.

Parrotta, P., Pozzoli, D., \& Pytlikova, M. (2014b). Labor diversity and firm productivity. European Economic Review, 66, 144-179.

Rapoport, H. (2018). Migration and trade. In A. 
Triandafyllidou (Ed.), Handbook of migration and globalization (pp. 173-191). Edward Elgar Publishing.

Rodríguez-Pose, A., \& von Berlepsch, V. (2018). Does population diversity matter for economic development in the very long term? Historic migration, diversity and county wealth in the US. European Journal of Population, 35(5), 873-911.

Spanish National Institute of Statistics. (2021). Main population series [Data set]. https://www.ine.es/ jaxi/Tabla.htm?path=/t20/e245/p08/10/\&file= 01001.px\&L=0

Sparber, C. (2010). Racial diversity and macroeconomic productivity across US states and cities. Regional Studies, 44(1), 71-85.

Suedekum, J., Wolf, K., \& Blien, U. (2014). Cultural diversity and local labour markets. Regional Studies, 48(1), 173-191.

Taras, V., Kirkman, B. L., \& Steel, P. (2010). Examining the impact of culture's consequences: A three-decade, multilevel, meta-analytic review of Hofstede's cultural value dimensions. Journal of Applied Psychology, 95(3), 405-439.

Trax, M., Brunow, S., \& Suedekum, J. (2015). Cultural diversity and plant-level productivity. Regional Science and Urban Economics, 53, 85-96.

\section{About the Authors}

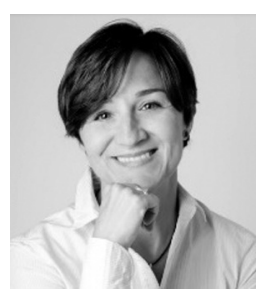

Maite Alguacil is associate professor and associate researcher at the Institute of International Economics at the Jaume I University. She has also been director of the MA in Economic Integration and International Trade. She coordinates the research group on international economics: Global Value Chains, Migration, Innovation and Adaptation to Climate Change (CAMINA). Her research interest focuses on the field of international economics and particularly in topics related with migration, trade, and foreign direct investments.

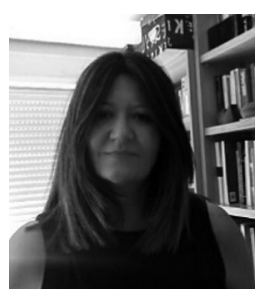

Luisa Alamá-Sabater is associate professor and associate researcher at the Institute of Local Development at Jaume I University. Her research interest areas are in the field of regional economy and in the topics related with population and employment dynamics and migrations flows. She has been director of the MA in Local Development and is member of research group of Regional Economy and Local Development (REALD) and Global Value Chains, Migration, Innovation, and Adaptation to Climate Change (CAMINA). 